\title{
The Advantages and Measures of Constructing Logistics Strategic Alliance for Chain Marketing Enterprises
}

\author{
Xiaogang Yang \\ Chengdu Normal University, Chengdu, China \\ Email:930761897@qq.com
}

Received 28 June 2016; accepted 15 July 2016; published 18 July 2016

Copyright @ 2016 by author and Scientific Research Publishing Inc. This work is licensed under the Creative Commons Attribution International License (CC BY). http://creativecommons.org/licenses/by/4.0/

\section{(c) (i) Open Access}

\begin{abstract}
The results indicated that the logistics strategic alliance has obvious advantages and benefits to economies of scale, and building strategic alliance of logistics is an effective way for the chain marketing enterprises to achieve economies of scale, which can enhance their core competitiveness. In this paper, the author pointed out the specific measures of the chain marketing enterprises to construct and consolidate logistics strategic alliance.
\end{abstract}

\section{Keywords}

Chain Marketing Enterprise, Logistics Strategic Alliance, Advantage, Scale Economy, Measure

\section{Chain Marketing Enterprises to Build Logistics Strategic Alliance Is to Enhance the Competitiveness of an Important Strategy}

With the gradual expansion of the scale of chain marketing enterprises, increasing the circulation of goods, domestic and international market competition is increasing, the chain marketing enterprises need to strengthen standardized management, and actively explore the distribution model for their own. Building a logistics alliance, to optimize logistics resources, reduce logistics costs, improve logistics efficiency and service level, achieve economies of scale of logistics, to become the enterprise "the third profit source", make him remain invincible in the competition the important strategic [1]. 


\section{The Advantages of Logistics Strategic Alliance of Chain Marketing Enterprises}

\subsection{Logistics Strategic Alliance to Promote the Integration of Logistics Services and Collaborative Development}

Integrated logistics service. With the increasingly fierce competition in the chain marketing enterprises, market demand is showing a diversification trend; enterprises wanting a good survival and development must provide the whole process of logistics service to customers in order to achieve the so-called integrated logistics service. The logistics enterprises need to achieve such purposes as the integration of resources, control and management etc., therefore they abandon the previous decentralized logistics services and gradually move towards the direction of integrated logistics enterprises [2]. Emphasized in the process of modern enterprise logistics service is the customer good supply chain management; multimodal transport, information services, transportation and other sectors have become the future development direction for logistics industry. Coordinate the development of the logistics industry. At present, many professional logistics enterprises emerged in the market; they have highly comprehensive service functions to form the good cooperation and build strategic alliances between the logistics enterprises, each with advantages of comprehensive cooperation.

\subsection{Logistics Strategic Alliances Can Further Improve the Economic Benefits of the Chain Marketing Enterprises}

Analyzed from the perspective of the economic benefit of enterprise, the use of logistics strategic alliances can let many chain marketing enterprises achieve intensive logistics operation mode and further reduce logistics cost. To hire professional industry logistics enterprises to bear the work of logistics services, in order to avoid too much input logistics resources, has important practical significance to the integration of some professional logistics resources.

\subsection{Logistics Strategic Alliance Can Shorten the Chain Marketing Enterprises Management Front}

Analyzed from the social point of view, the logistics agency as the main part, unified planning and implementation, effectively reduces the rate of repeated labor in the process of social logistics; low level, professional operation is undertaken by the corresponding group of the institutions, which is in line with the specific requirements of the professional division of labor. The chain marketing enterprises must be effective in management and control of the strategic alliance, to ensure that it can be under good operation according to the requirements of customers and business norms [3]. An inevitable trend of the development of modern logistics industry in the process is the transition of operation layer to management.

\subsection{Logistics Strategic Alliance Can Transfer Risks}

Chain marketing enterprises by actively looking for strategic alliance partners ensure that the common risks in the operation process are shared so as to reduce their risk and uncertainty. The risk of chain marketing enterprises specifically covers three aspects, namely, social risk, financial risk, social risk. Social risk is mainly due to the change of policy and traffic regulations, while the goods risk mainly comes from the occurrence of the transport of goods inventory, safety related factors and damage caused in the process of transportation of goods; Funding risk is mainly from time value of receivables. Chain marketing enterprises should as soon as possible build logistics strategic alliances to transfer all kinds of risks. For instance, the occurrence of financial risk can be avoided through the use of strategic alliances to further extend the payment period, so as to realize the optimization of settlement pattern.

\section{An Economic Analysis on the Scale Economy of Logistics Strategic Alliance of Chain Marketing Enterprises}

Chain marketing enterprises differ from the general production enterprises. The actual production is not based on corporeal entity; rather, it mainly provides the whole process of sales and service to the majority of customers. Therefore, the chain marketing enterprises' constructing logistics strategic alliance not only can realize economies of scale target flow, but also can make the operation of logistics enterprises achieve economies of scale. 


\subsection{Chain Marketing Enterprise Logistics Strategic Alliance Can Enable Enterprises to Achieve Economies of Scale}

Enterprise logistics chain marketing scale economy specifically covers two aspects; one is that the enterprise logistics industry has been expanding, the other is that logistics market scope has been further expanded. During the actual operation, because the individual enterprise is weak relying on their own strength, part of marketing activities that should be covered or expected to see business get in is difficult to enter for the chain enterprise logistics, and even if they can enter, there are needs for a large entry costs which cannot make its value fully reflected after entering. If each chain marketing enterprise builds logistics strategic alliance, with the strength of the alliance, they will be able to complete the logistics activities that enterprise on itself would be unable to do, thus effectively reduce various forms of cost in the logistics activities of individual enterprises and further expand the scope of logistics, resulting in good economies of scale [4].

\subsection{Chain Marketing Enterprise Logistics Strategic Alliance Can Promote the Formation of the Scale Effect of Logistics Operation}

The construction of logistics strategic alliance of chain marketing enterprises can produce the effect of logistics operation scale, which is mainly reflected in the following aspects: first, to optimize the efficiency of transportation. The transportation chain marketing enterprises transfer the transportation part of logistics activities to certain partners with transportation advantage. This can make the transportation more reasonable, transport routes economic, and transport goods quantified, which reduces the average cost and at the same time, improve the level of service. Second, reasonable storage. The chain marketing enterprises, through the construction of logistics strategic alliance, can achieve unified planning of the existing warehouse, reasonable arrangements for the storage of goods and effective prevention of warehouse idleness or shortage in individual enterprises, which thus save various facilities in the warehouse to ensure its good use; Third, to achieve information sharing. The chain marketing enterprises' constructing logistics strategic alliance can make business information shared and effective business processes of the comprehensive integration and operational efficiency improved [5]. The abovementioned series of operation scale effects produced when the chain marketing enterprises construct logistics strategic alliance should be reflected in terms of cost performance by further reduced transaction costs of enterprises, inventory cost, and investment cost. Following is the analysis on the cost.

\subsection{Chain Marketing Enterprise Logistics Strategic Alliance Can Effectively Reduce the Cost of Logistics}

Analysis on enterprise transaction cost. It is essential for modern enterprise's survival and development to provide the whole process of service to our customers, but for many marketing enterprises, there is often a lack in the ability to perform the service mode of the whole process; they still have some transactions, and the actual transaction process will produce transaction cost, greatly improving user cost. The marketing enterprises through the construction of logistics strategic alliance, can make the user cost effectively controlled. Firstly, from the perspective of the actual transactions, between each enterprise there is communication and cooperation, effectively preventing the blindness of trading phenomenon. Also they do not have too much cost in the searching of the object transactor's information; the marketing enterprises can construct a set of feasible procedures and practices through the alliance as soon as possible in order to complete the transaction related matters. The actual transaction bargaining cost is thus reduced to a minimum; by the construction of strategic alliance, contingency ability of both parties in face of the changing environment can be greatly enhanced. Secondly, analyzed from the perspective of the behaviour of transactions subject, the federation of enterprises, after long-time cooperation, effectively complete the previous complex transaction behavior through the construction and implementation of a one-time alliance agreement, which also prevent other selfish behavior of both parties of the transaction, thereby reducing the cost of supervision of contract execution.

Analysis of inventory cost. The customized services and one-time sales demand are implemented by chain marketing enterprise, but the size and strength of some enterprises is relatively scarce with low distribution capacity. In order to respond timely to customers and avoid the shortage problem, enterprises often make a perfect series of strategy with high level of inventory, maintaining a large inventory at points all scattered [6]. In this way, enterprises not only take up a lot of money, but also improve the rate of inventory, resulting in further reduction 
of corporate liquidity. Due to the excessive inventory investment, the enterprise capital turnover is very difficult. As long as the establishment of logistics strategic alliance between marketing enterprises is achieved, basic principles of complementary advantages always followed, and the sharing mechanism of advantages in each part of the value chain built, a variety of resources can be comprehensively centralized to overcome the existing weakness of each enterprise, thus further enhancing distribution capabilities and reducing the enterprise warehouse and safety stock as much as possible. In addition, alliance can also, according to the actual demand of each chain marketing enterprises, conduct unified planning. In some of the more concentrated dispersion order point location, a large warehouse can be built for the implementation of centralized storage to obtain various benefits.

Analysis on the cost of investment. Investment costs specifically cover the infrastructure, tools such as transportation, warehouse, transportation tools, and human resources. Many chain marketing enterprises have their own logistics facilities, such as transportation, warehousing and so on. But these facilities are strongly professional, resulting in a sunk cost between the fixed cost in the investment process and the cost which change along with the change of the output level. The chain marketing enterprises, by the construction of logistics strategic alliance, change formerly professional assets to total assets of all enterprises, effectively reducing the enterprise cost of investment. Chain marketing enterprises logistics strategic alliance is shown in Figure 1.

Assuming market established labor price is $\mathrm{M}, \mathrm{N}$ is the price of certain capital, number of employees necessary for logistics activities is $\mathrm{L}$, logistics facilities capital inputs is $\mathrm{K}$, and enterprise established logistics costs is $\mathrm{C}$, then logistics cost function can be shown with the following formula: $\mathrm{C}=\mathrm{ML}+\mathrm{NK}$. Now take chain marketing enterprise 1 and enterprise 2 as examples, the cost can be expressed as follows: C1 = ML1 + NK1, C2 = ML2 + NK2. If the two chain enterprises form a logistics strategic alliance, the logistics costs can be expressed as follows: C3 = ML3 + NK3. According to what is shown in Figure 1, when the chain marketing enterprises outsources the weak business in its process, then you can avoid investment in facilities in the outsourced part, mainly including investment in equipment spending for those engaged staff in logistics and investment in logistics infrastructure, and thus we have the relationship of such as L3 $<\mathrm{L} 1+\mathrm{L} 2, \mathrm{~K} 3<\mathrm{K} 1+\mathrm{K} 2$, which derives that C3(L3, K3) < C1(L1, K1) + C2(L2, K2). That is, after the establishment of logistics strategic alliance, enterprises can reduce the staff's equipment spending and capital investment in logistics facilities, smoothly realize the logistics total investment cost reduction [7].

\section{Measures for Chain Marketing Enterprises to Build and Consolidate the Logistics Strategic Alliance}

\subsection{Preferred Logistics Strategic Alliance Partners}

Chain marketing enterprises should choose the appropriate logistics strategic alliance partners, should as soon as possible establish a set of index system of feasible evaluation standard that can fully reflect the overall strength of the coalition partners. In the process of selecting partners, not only should the quality, cost, delivery efficiency and distribution capabilities be fully considered, at the same time, but also the formation of good strategic cooperative relations between enterprises should be ensured. In addition, it is necessary to assess indicators of all aspects including the partner's past experience, such as industry Business Hours, cost saving, management

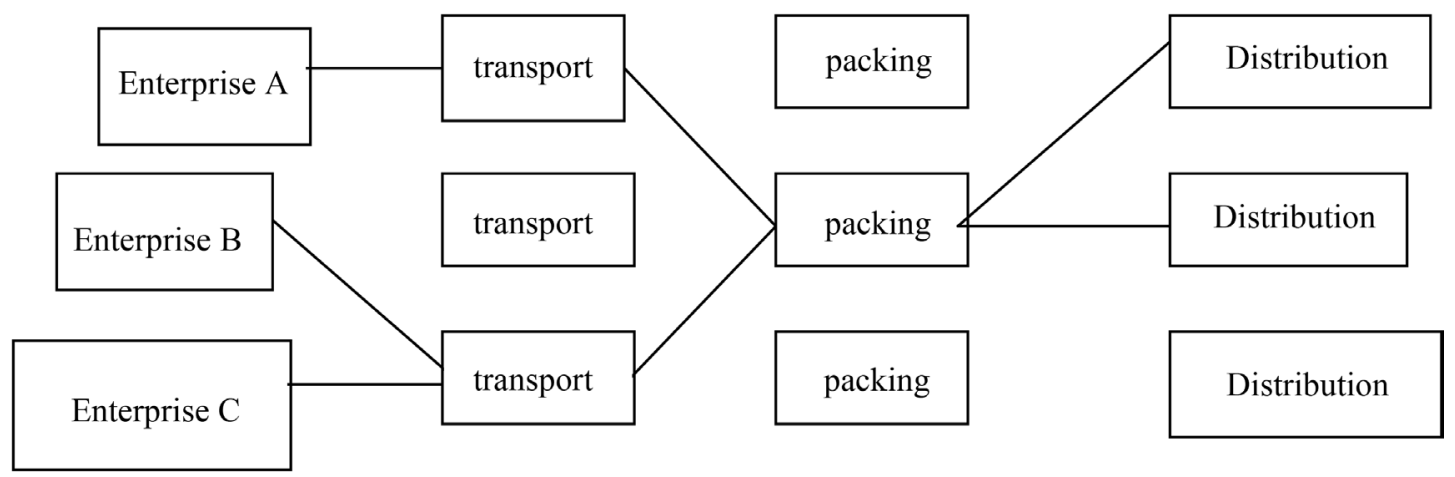

Figure 1. Chain marketing enterprise logistics strategic alliance schematic diagram. 
experience, information technology capability, financial capability as well as the amount of support to the alliance from its management and so on. Finally, a set of scientific and reasonable evaluation methods should be formulated. For example, due to a lot of uncertainty and fuzziness covered in actual evaluation process, the AHP model should be constructed to select suitable partners.

\subsection{Strengthen Contract Management}

The connection means between chain marketing enterprises alliance is a contract. The contract generally can be divided into two types, that is, contracts that make clear long-term cooperation between the partners, and, secondly, short-term contracts in the daily management of the enterprise. Although the contract can further standardize the behavior of partners, the content design still has some shortages which finally fail to effectively control some logistics operations of the partners in the logistics strategic alliance, so the two sides, in the process of signing a sub contracting, should pay special attention to the following points:

First, enterprises should actively construct the dynamic chain marketing activities and dynamic inspection and control mechanism. Because of the organizational structure, logistics strategic alliance is temporary and loose and therefore should construct a dynamic type of contract, that is to say, the contents of the contract should be combined with the contract work progress and changes in the market to develop a series of corresponding provisions and also, should adopt various forms of contract in the contract on the basis of sequence, such as the provisions that the entry into the next contract can only be done upon the completion of current task in current contract with fulfillment of the requirements and specifications. In addition, all the logistics contract is provided with a check clause, if partners cannot achieve specifically so, the contract is invalid. Therefore, the actual implementation of the dynamic contract should check the dynamic mechanism and configuration, so as to effectively control the logistics behavior of partners to avoid the occurrence of contract risk. For example, in the logistics points contract, an index system that can fully reflect the enterprise performance can be constructed to regulate provisions of specific performance needed to be achieved, allowing a full range of inspection and control of cooperative partner's performance behavior.

Second, construct perfect risk sharing and risk supervision and control mechanism. Because of incomplete and asymmetric information, the entrusting party is usually in the less favorable position than the partners, which may eventually lead to the occurrence of information risk. For example, as a result of the fact that the partner knows information which the entrusting party doesn't know and which is detrimental to the entrusting party, they eventually signed contracts that are for the partner's own benefit and does serious damage to the interests of the entrusting party. In order to effectively prevent the occurrence of various risks, we must further clear alliance specific degree and related interests to develop a set of perfect and feasible risk sharing and risk supervision and control mechanisms [8].

\subsection{Construct Efficient Incentive Mechanism}

Marketing enterprises, by establishing an efficient incentive mechanism, can continuously improve the attractiveness of the alliance to the allies, and partners would try their best to complete the task, thus prevent the occurrence of selfish behavior such as dishonest information disclosure. For example, if some partners complete the tasks in accordance with the relevant requirements, they will get the subcontracting opportunities of the next stage project as an encouragement to enhance their performance; in this way, the enthusiasm for alliance cooperation is fully improved. In addition, the construction of incentive mechanism should also combine explicit and implicit incentives. The former incentive mechanism refers to the reward and punishment in accordance with the final observations of partner's performance because the entrusting party cannot have real-time control while expecting the partner to act upon choices that are consistent with their desired behavior. This mechanism is often used in short-term contracts. In order to form long-term relations of cooperation with partners, the principal should refer to previous related variables on partner effort level to form accurate inference, in order to construct the implicit incentive mechanism, so as to avoid partners using shirking behavior to gain selfish interests.

To sum up, the economic globalization has brought enormous pressure to the competition of logistics marketing enterprises. If chain marketing enterprises want to be in an invincible position in the fierce competition in the market, it is necessary to construct the logistics strategic alliances to enhance their own competitiveness and ensure that enterprises maximize economies of scale. Through the construction of logistics strategic alliance, to prevent the occurrence of vicious competition behavior, to ensure that the normal market competition order, 
through cooperation and development, the development of effective measures to prevent the occurrence of various risks, so that the chain marketing enterprises access to many of the economies of scale.

\section{References}

[1] Lu, L. (2016) Study on the Optimization Model of Commercial Circulation Industry Convergence under the View of Logistics Chain. Business Economic Research, No. 9, 13-15.

[2] Xiong, M.P. (2006) Study on the Logistics Alliance of Chain Operation. Jiangxi University of Finance and Economics, Nanchang.

[3] Hang, H.L. (2011) Logistics Distribution Mode Based on the Retail Chain Supermarket. Economic and Trade Forum, No. 1, 68, 70

[4] Lan, T. and Xu, J. (2008) On the Distribution Mechanism/Method of Interests Among Enterprises in Dynamic Alliance. Journal of Northeastern University (NATURAL SCIENCE EDITION), No. 2, 301-304.

[5] Li, Y. (2008) Strategic Alliance Theory and the Strategic Choice of Enterprise Alliance. Business Era, No. 22 , 40-41.

[6] Zhou, J. (2015) Based on the Logistics Alliance of the Logistics Development of the New Format of the Northern. North Economic and Trade, No. 2, 20-21, 23.

[7] Li, C.C. and Feng, X.F. (2009) Analysis of the Growth Model of China’s Logistics Enterprises. Public Business, No. 4, 23, 34.

[8] Zheng, W.L. (2016) Chain Supermarket Supply Chain of Agricultural Products Logistics Distribution System to Build. Business Economic Research, No. 11, 91-92.

\section{Submit or recommend next manuscript to SCIRP and we will provide best service for you:}

Accepting pre-submission inquiries through Email, Facebook, LinkedIn, Twitter, etc. A wide selection of journals (inclusive of 9 subjects, more than 200 journals)

Providing 24-hour high-quality service

User-friendly online submission system

Fair and swift peer-review system

Efficient typesetting and proofreading procedure

Display of the result of downloads and visits, as well as the number of cited articles

Maximum dissemination of your research work

Submit your manuscript at: http://papersubmission.scirp.org/ 